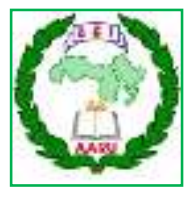

Arab Univ. J. Agric. Sci., Ain Shams Univ., Cairo, Egypt

29(1), 375 - 385, 2021

Website: http://ajs.journals.ekb.eg

DOI: 10.21608/ajs.2021.27690.1333

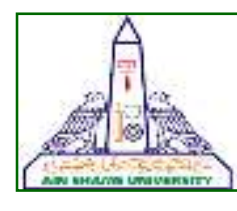

\title{
Effect of New Solar-Drying Designs for Chamomile Essential Oil Yield and Its Chemical Constituents in Egypt
}

\author{
Mohamed RA Abutaleb ${ }^{*}$, Tamer IM Ragab², Yosry A Abdeldaim', \\ Alaa A Mohamed ${ }^{1}$
}

1- Food Science Dept, Faculty of Agriculture, Ain Shams University, 11241, Cairo, Egypt

2- Chemistry of Natural and Microbial Products Department, Pharmaceutical Industry Division, National Research Centre, Giza, 12622, Egypt

*Corresponding author: mohamed88refaat@ gmail.com

Received 12 February, 2021

Accepted 7 April, 2021

\begin{abstract}
Egyptian medicinal and aromatic plants (MAPs) sector suffers from poor drying conditions of the product in terms of quality and safety standards, lack of professional advisory services, in addition to a high undeveloped value chain. Four designs were established in this study and focused on different methods for chamomile drying, the results of the 8/9/2 (B) design of the solar-assisted stack dryer were a masterpiece and promising for drying chamomile plant. The results of volatile oil extraction showed that an increased yield of volatile oil extraction by $30 \%$ compared with traditional drying methods (control). GC-MS analysis indicated the essential oil chemical composition for the new drying method, were found to be the main active compound Bisabolol oxide $\mathrm{A}$ which were $54 \%$ in 8/9/2 (B) design of the solar-assisted stack dryer compared with the control which was $38.36 \%$ in control. The study method was promising and distinctive because it increases the yield of volatile oil extraction, maintains chemical structure compared with the control.
\end{abstract}

Keywords: Chamomile; Solar-assisted stack dryer; Volatile oil; GC-MS; Traditional drying methods

\section{Introduction}

Medicinal and aromatic plants (MAPs) are one of the most important export crops in Egypt, as they occupy the first rank in terms of the ratio of export production, where approximately $90 \%$ of production is exported. The United States, European Union, and Arab countries are the largest importers of Egyptian medicinal and aromatic plants (Lange 2006). Dry herbs have awesome significance, not as they were for culinary purposes, but too for medical uses (Hedrick 1972). Herbs, spices, medicinal and aromatic plants from family Lamiaceae like peppermint (Menthapiperita), sweet basil (Ocimumbasilcum L.), and rosemary (Rosmarinus officinalis L.), are cosmopolitan in Egypt. These plants are used as spasmolytic, stomachic, carminative, and expectorant agents in folk medicine and in official medicine. Other benefits may well be applied because of ethereal oils in therapeutic purposes owing to their antimicrobial (bactericidal and fungicidal) effects on some pathogenic microorganisms (Stefanini et al 2001, Klaus et al 2008). Chamomile (Matricaria recutita L.) (Family Asteraceae), is a well-known medicinal plant in folk medicine cultivated all over the world. Chamomile oil is widely employed in the pharmaceutical, cosmetic, and food industries. The pharmacological effect of 
chamomile oil for its spasmolytic, antimicrobial, and disinfection properties (Brunke et al 1992, Grgesina et al 1995). In Egypt, natural sun drying is one of the most common ways to keep agricultural products safe. The moisture is carried away by the wind as it blows above the product. It is affected by drying conditions, types of dryers, and characteristics of materials to be dried. The drying curve of dryers will give information on the time necessary for a product to be dried under certain conditions (Senadeera et al 2003, Ramaswamy and Marcotte 2005, Giri and Prasad 2007). Generally, the preservation factor in drying is to reduce the degree of moisture contained to the extent that it inhibits the activity of microorganisms and enzymes and reduces chemical reactions that lead to corruption (Ajay et al 2009). Many researchers have established the positive effect of low temperature drying in conjunction with low relative humidity $(\mathrm{RH})$ in improving the product quality (Adapa et al 2002, Alves-Filho 2002, Sosle et al 2003). Modern methods for designing air drying operations depend on the mathematical description of plant moisture movement during the process (Hernandez et al 2000). This study focused on the improvement of the basic farmers' drying technology as direct sun drying in the open air. A properly designed solar dryer, which used low cost, environmental materials, can alleviate the drawbacks related to open sun drying and improve the quality standard of the dried product considerably. The drying kinetics factors (airflow, air velocity, pressure, temperature, and relative humidity) were determined. The essential oils of drying samples were extracted; their biological activities were determined and compared with controls.

\section{Materials and Methods:}

\subsection{Plants}

Fresh plant was used in drying trials; chamomile (Matricaria chamomilla) was purchased from SEKEM company, El-Sharkia governorate, Egypt.

\subsection{Stack dryers for small-scale map grow- ers in Egypt}

Different designs for forced ventilation stacks have been developed and the required fan size in terms of air flow rate and pressure has been estimated.

\subsubsection{Basic design (Design 1)}

Ten single stacks ( 10 boxes in height, =layers) were located in a row. Two rows were situated in parallel without space in-between. The stacks were covered with a plastic film and the air was sucked out through the boxes in cross-flow made by the radial vacuum fan. The design was similar to the forced air cooling of vegetables as shown in (Fig 1). The height of the stacks and the length of the rows are variable, the design is highly flexible. Furthermore, the capacity of the dryer depends on several variables such as drying rate, bulk density, moisture content, temperature, as well as saturation deficit of the drying air.

\subsection{Design of solar-assisted stack dryer}

The trials of drying of medicinal and aromatic plants during winter had revealed a low drying rate; the temperature of drying air was increased by incorporating a solar collector section. The dryer was placed on a layer of MAP stalks for heat insulation from the ground. The collector section at the entrance of the stack dryer was built with empty boxes. Several layers of black shading net serve as absorber. Empty boxes serve as top- and bottom layer of the stack dryer to create an air gap between the plastic foil and the drying material showed in supplementary data. Three sizes of over-flow stack dryers have been constructed and tested. The size is expressed following code: \#layers/\#stacks/\#rows. The sizes were $1 / 9 / 2,5 / 5 / 2$ and $8 / 9 / 2$. The limiting factor for the larger sizes was the number of available boxes on site. 

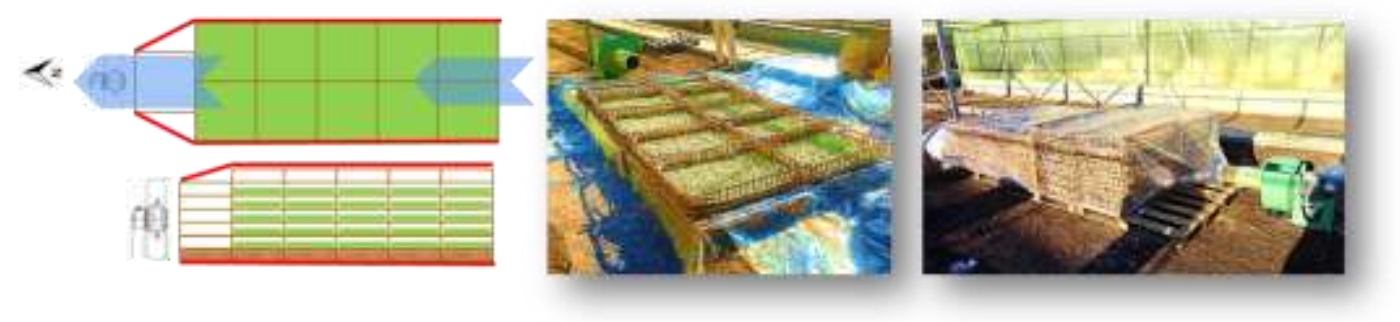

Fig 1. Basic design (Design 1)

\subsubsection{1/9/2 design of solar-assisted stack dryer (Design 2)}

The 1/9/2 stack dryer was a version with one layer of filling, drying boxes with 9 stacks in a row and two rows in parallel. Two empty stacks have been added as a solar collector. Open dryer at the end of drying and closed dryer. The experimental set- miniature data loggers (L1-L3) for measuring T and RH have been placed at the inlet of the up includes three collector segment and at the inlet and outlet of the dryer segment as showed in (Fig 2). Three miniature data loggers (L1-L3) were placed at the inlet of the collector segment and at the inlet and outlet of the dryer segment.

\subsubsection{5/5/2 design of solar-assisted stack dryer (Design 3)}

The 5/5/2 stack dryer was a version with five layers of filling, drying boxes with five stacks in a row and two rows in parallel. Five empty stacks have been added as solar collectors. Three miniature data loggers (L1-L3) for measuring $\mathrm{T}$ and $\mathrm{RH}$ have been placed at the outlet of the dryer segment and six (L4-L9) have been placed at the inlet (Fig 3). Ambient $\mathrm{T}$ and RH have been measured by a further logger L10 and by logger with display D1. At the start and towards the end of drying air velocity $(\mathrm{Q})$ and static pressure $(\mathrm{P})$ have been measured by handheld devices at the inlet of the collector segment, the inlet and the outlet of the dryer, where $(\mathrm{Q})$ has been measured at the top, middle and bottom position for left and right row. Air flow (V) has been measured by Heavy Duty Pitot Tube Anemometer and Differential Pressure Manometer (Model HD350).

\subsubsection{8/9/2 design of solar-assisted stack dryer (Design 4)}

The 8/9/2 stack dryer was a version with eight layers of filling, drying boxes with 9 stacks in a row and two rows in parallel between each two layers of drying boxes a layer of empty boxes was placed to allow sufficient air ventilation. Two empty stacks have been added as a solar collector and another two empty stack as a head unit to attach the fan. This construction was allowed to open the middle part of the dryer conveniently to handle the drying boxes. Three miniature data loggers (L5-L6) for measuring $\mathrm{T}$ and $\mathrm{RH}$ have been placed at the outlet of the dryer segment and three (L7-L9) have been placed at the inlet (Fig 4). Ambient $T$ and RH have been measured by a further logger L3 and by logger with display D1. At the start and towards the end of drying air velocity $(\mathrm{Q})$ and static pressure $(\mathrm{P})$ have been measured by handheld devices at the inlet of the collector segment, the inlet and the outlet of the dryer, where $(\mathrm{Q})$ has been measured at the top, middle and bottom position. Air flow (V) has been measured by Heavy Duty Pitot Tube Anemometer. 


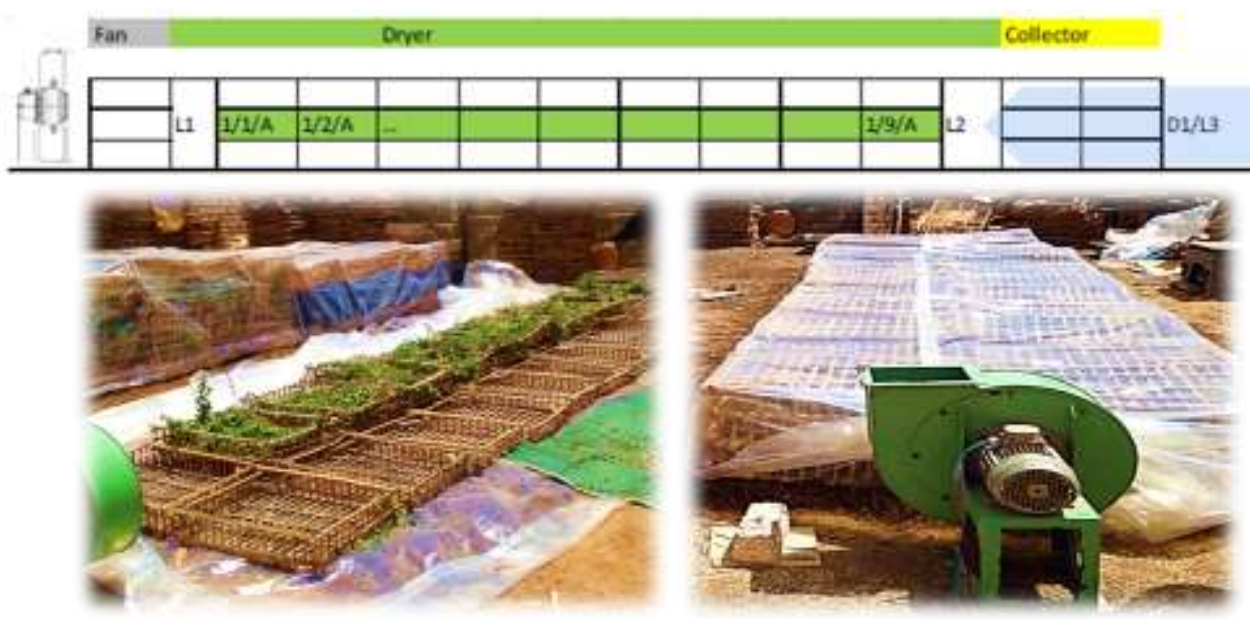

Fig 2. 1/9/2 design of solar-assisted stack dryer (Design 2)
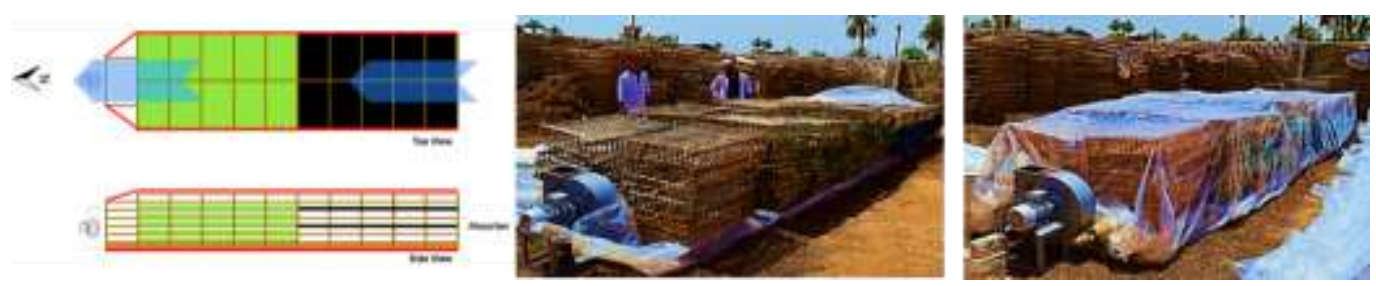

Fig 3. $5 / 5 / 2$ design of solar-assisted stack dryer (Design 3)

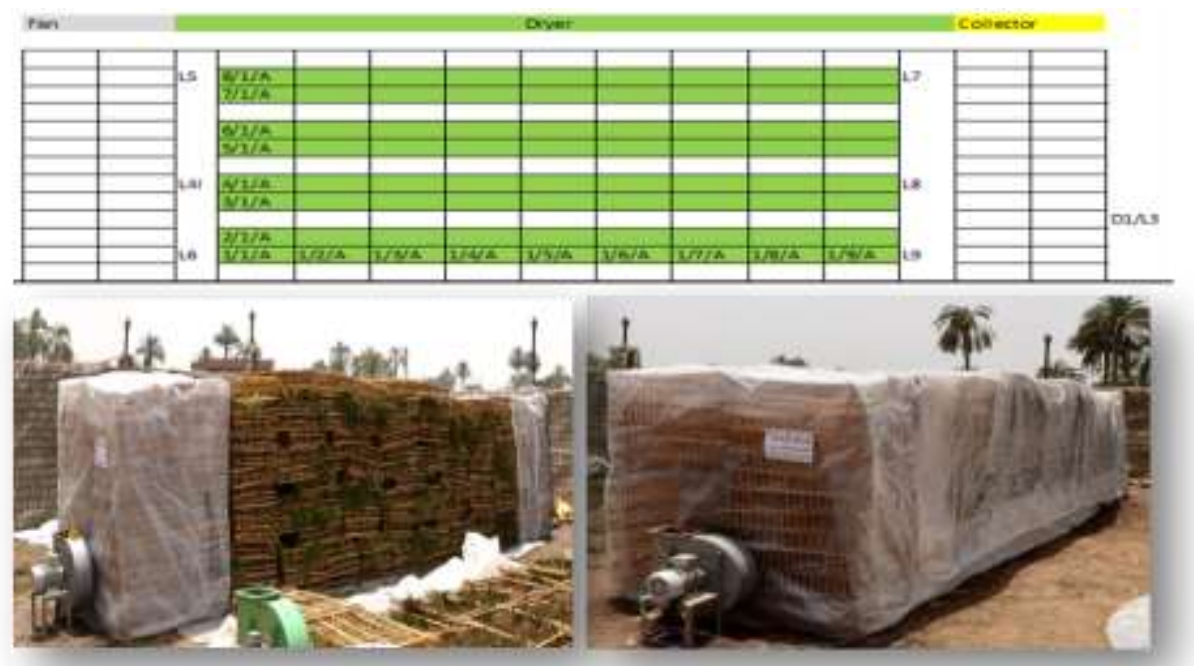

Fig 4. 8/9/2 design of solar-assisted stack dryer (Design 4) 

Oil Yield and Its Chemical Constituents in Egypt

\subsection{Operation time and energy consumption}

The drying chamomile could be started for 10 hours daily for 8 days with a break in-between opening the dryer, mixing the drying material and inversing the vertical position of the layers. The energy consumption was 240 $\mathrm{kWh}$ for chamomile with stack dryer designs $1 / 9 / 2,5 / 5 / 2,8 / 9 / 2$ (A) and $300 \mathrm{kWh}$ for $8 / 9 / 2$ (B) design with extra 2 workdays.

\subsection{Essential oil extraction and determina- tion}

The volatile oils were extracted from fresh and dried chamomile by using a hydro-distillation Clevenger apparatus method. Samples from fresh and dried plants $(100 \mathrm{~g})$ were cut into small parts and suspended in $1250 \mathrm{ml}$ of distilled water. The mixture was kept boiling for four hours. The extracted essential oils were dried over anhydrous sodium sulfate to remove all the water and then stored in darksealed-vial at $4{ }^{\circ} \mathrm{C}$ for further tests. The extracted oil percentage was calculated, according to (Guenther, 1975) using the following equation 1 :

$$
\mathrm{X} 0=\rho 0 \times \mathrm{V} 0 \times \mathrm{WL} \quad \text { (Equation } 1)
$$

Where:

$\mathrm{X} 0$ - Percentage of the volatile oil, $\%, \rho 0$ Density of the volatile oil, (g/cm3), V0 - Volume of the volatile oil, (cm3), WL - Weight of sample, $(100 \mathrm{~g})$.

\subsection{Chemical composition of essential oil by GC-MS analysis}

The gas chromatography-mass spectrometry (GC-MS) analysis of the chamomile volatile oil samples was loaded by utilizing the gas chromatography-mass spectrometry device. The GC Ultra Gas Chromatographs TRACE (THERMO Scientific Corp., USA), coupled by a THERMO mass spectrometer detector (ISQ Single Quadrupole Mass Spectrometer). The gas chromatography-mass spectrometry system was equipped with a TR-5 MS column
(30 $\mathrm{m} \times 0.32 \mathrm{~mm}$ i.d., $0.25 \mu \mathrm{m}$ film thickness). The analysis was loaded by using a stable gas it was a helium gas, as the helium at a flowrate of $1.3 \mathrm{ml} / \mathrm{min}$ and a split ratio of $1: 10$ using the following temperature program was: $60^{\circ} \mathrm{C}$ for $1 \mathrm{~min}$; rising at $4.0^{\circ} \mathrm{C} / \mathrm{min}$ to $240^{\circ} \mathrm{C}$ and wait for $1 \mathrm{~min}$. The injector and detector were put at $200{ }^{\circ} \mathrm{C}$. Samples were diluted (1:10 hexane, $\mathrm{v} / \mathrm{v}$ ) of $1 \mu \mathrm{L}$ of the mixtures was always injected. Mass spectra were reached by electron ionization (EI) at $70 \mathrm{eV}$, using a spectral range of $\mathrm{m} / \mathrm{z} 40-450$. Chemical constituent of the EOs under investigations was characterized by Automated Mass spectral Deconvolution and Identification (AMDIS) software (www.amdis.net), retention indexes (relative to $n$-alkanes $\mathrm{C}_{8}-\mathrm{C}_{22}$ ), comparison of the mass spectrum with authentic (if available), and Wiley spectral library collection and NSIT library database (Gaithersburg, MD, USA; Wiley, Hoboken, NJ, USA).

\section{Results and Discussion}

\subsection{Stack dryers for small-scale map grow- ers in Egypt}

\subsubsection{Basic design}

The basic design was not adjustable enough drying for the reason that plants still green in the bottom and the middle of the boxes, there was a black spots regards to enzymatic and microorganism activity, the first level on the top was dry, conversely the plants burned because of the direct exposure to the sun. The result was not accepted in drying medicinal and aromatic plants, which selected in our trial. Meanwhile, additional designs were developed enough drying and avoid the drawbacks to meet the farmer's needs.

\subsubsection{1/9/2 Solar-assisted design}

The fans were not operated during the night as not much evaporation was to be expected from the semi-dry material and relative humidity was high at night, and it will raise the moisture ratio of plants. The air flow rate was indicated that the very important factor in the 1/9/2 
solar-assisted design and operation of lowtemperature drying systems regardless of whether natural air or heated air was used.

The obtained results of 1/9/2 design solarassisted stack dryer was succeeded in chamomile, which we were selected in our experiments, nevertheless 1/9/2 design had a problem, it took a little number kilograms of plants (every box take $2.5 \mathrm{~kg}$ of fresh plants maximum, and 1/9/2 design of solar-assisted stack dryer had 18 boxes, so the drying batch $45 \mathrm{~kg}$ of fresh plant), accordingly, a newly developed design needed to possess a much bigger design meets the farmer's needs for production. In general, the physical properties measurements of solar-assisted stack dryer designs differ from one to another depending on layers, stacks, rows, environment, season, nature of plants, and the moisture content (Pierce and Thompson 1980).

\subsection{3 $5 / 5 / 2$ solar-assisted design}

The results of the 5/5/2 design dryer were adequate in drying chamomile, which nominated in the trial, however, the design contains a problem, it obtained a bit number of kilograms of plants (every box $2.5 \mathrm{~kg}$ of fresh plants maximum, and 5/5/2 design have 50 boxes, that the drying batch $125 \mathrm{~kg}$ of fresh plant), The study focused on a new drying model that took larger quantities than the current one.

\subsubsection{8/9/2 (A\&B) solar-assisted design}

The layers, stacks, rows, environment, season, nature of plants, and the moisture content effect on solar-assisted stack dryer.

\subsection{Essential oil extraction of testing sam- ples Essential oil extraction of testing sam- ples}

The average yield of essential oil extraction of testing samples $/ 100 \mathrm{~g}$ dried chamomile, and mint was determined. The control samples were $0.7 \pm 0.01 \mathrm{ml}$ in chamomile, and $0.6 \pm$ $0.01 \mathrm{ml}$ in mint (Fig 5). In case of designs, the samples were taken from 8/9/2 (B) design since it was achieved the lowest moisture content with the highest mass production of all designs. The average of essential oil extracted from 8/9/2 (B) design of chamomile samples was $1 \pm 0.01 \mathrm{ml}$, and in mint was $0.9 \pm 0.01$ $\mathrm{ml}$. This means that increasing yield of essential oil extraction by $30 \%$ by using $8 / 9 / 2$ (B) design compared with traditional drying methods (control).

\subsection{Chamomile essential oil chemical con- stituents Chamomile essential oil chemical constituents}

From the data showed in Table 1, results indicated that the percentage of a total of the 38 chamomile major components, shows 99.99\% hydro-distillation extraction of the total oil in both samples (control and 8/9/2 (B) design). Bisabolol oxide A (C15H26O2) was a major compounded with higher percentage $54.00 \%$ in chamomile extracted oil from 8/9/2 (B) design, accordingly there was a significant range compared with $38.36 \%$ in control chamomile. $\alpha$-Bisabolol oxide B was $8.98 \%$ in chamomile extracted oil from 8/9/2 (B) design, meanwhile there was a significant range compared with $8.12 \%$ in control chamomile oil, however chamazulene was $3.36 \%$ in the control compared with $0.99 \%$ in chamomile extracted oil from 8/9/2 (B) design of solar-assisted stack dryer. Bisabolone oxide was 7.41 $\%$ in chamomile oil extracted from control compared with $6.86 \%$ in chamomile extracted oil from 8/9/2 (B) design of solar-assisted stack dryer. In the control sample some compound were not determined like (Caryophylleneoxide, Santalol, cis, $\alpha$-, o-Toluidine, limonen -6-ol, pivalate, 4-Methyl-2H-pyrano[6,5h]-2H-chromen-2-one, Azulen-2-ol,1,4-dimethyl-7-(1-methylethyl), Geranyl isovalerate, and Docosane), nonetheless, it was determined in $8 / 9 / 2$ (B) design sample. Furthermore, in $8 / 9 / 2$ (B) design there were some compound were not determined like ( $\beta$-Ocimene, trans caryophyllene, trans-p-mentha-2,8-dienol, Ledene, Farnesene, $\beta$-Cdainene, $\delta$-Cadinene, Globulol, and Bisabolol oxide A). Fig 6 showed GC-MS chromatogram of essential oil 

Oil Yield and Its Chemical Constituents in Egypt

Table 1. Chamomile essential oils chemical composition and its control oil

\begin{tabular}{|c|c|c|c|c|c|c|}
\hline & \multirow[b]{3}{*}{ KI } & \multicolumn{2}{|c|}{$\begin{array}{c}\text { Chamomile } \\
\text { essential } \\
\text { oils } \\
\end{array}$} & \multirow[b]{3}{*}{ Compound name } & \multirow[b]{3}{*}{ Formula } \\
\hline & & & \multirow{2}{*}{$\begin{array}{l}\text { Control } \\
\text { Area \% }\end{array}$} & \multirow{2}{*}{$\begin{array}{c}/ 9 / 2(\mathrm{~B}) \\
\text { design }\end{array}$} & & \\
\hline No. & RT & & & & & \\
\hline 1 & 7.20 & 1245 & 0.57 & nd & $\beta$-Ocimene & $\mathrm{C} 10 \mathrm{H} 16$ \\
\hline 2 & 7.67 & 1065 & 0.97 & 0.55 & Artemisia ketone & $\mathrm{C} 10 \mathrm{H} 16 \mathrm{O}$ \\
\hline 3 & 22.35 & 1412 & 0.18 & nd & trans caryophyllene & $\mathrm{C} 15 \mathrm{H} 24$ \\
\hline 4 & 24.06 & 1442 & 19.64 & 7.88 & cis- $\beta$-Farnesene & $\mathrm{C} 15 \mathrm{H} 24$ \\
\hline 5 & 24.47 & 1122 & 0.27 & nd & trans-p-mentha-2,8-dienol & $\mathrm{C} 10 \mathrm{H} 16 \mathrm{O}$ \\
\hline 6 & 25.00 & 1500 & 2.54 & 0.40 & GERMACRENE-D & $\mathrm{C} 15 \mathrm{H} 24$ \\
\hline 7 & 25.32 & 1490 & 0.37 & nd & Ledene & $\mathrm{C} 15 \mathrm{H} 24$ \\
\hline 8 & 25.55 & 1738 & 1.72 & 0.17 & Bicyclogermacrene & $\mathrm{C} 15 \mathrm{H} 24$ \\
\hline 9 & 26.04 & 1674 & 1.56 & nd & Farnesene & $\mathrm{C} 15 \mathrm{H} 24$ \\
\hline 10 & 26.40 & 1519 & 0.87 & nd & $\beta$-Cadainene & $\mathrm{C} 15 \mathrm{H} 24$ \\
\hline 11 & 26.48 & 1530 & 0.52 & nd & $\delta$-Cadinene & $\mathrm{C} 15 \mathrm{H} 24$ \\
\hline 12 & 28.33 & 1624 & 0.24 & 0.28 & Farnesene epoxide & $\mathrm{C} 15 \mathrm{H} 24 \mathrm{O}$ \\
\hline 13 & 28.58 & 1573 & nd & 0.21 & Caryophyllene oxide & $\mathrm{C} 15 \mathrm{H} 22 \mathrm{O}$ \\
\hline 14 & 28.88 & 1640 & 0.68 & 1.77 & (-)-Spathulenol & $\mathrm{C} 15 \mathrm{H} 24 \mathrm{O}$ \\
\hline 15 & 29.18 & 1570 & 0.24 & nd & Globulol & $\mathrm{C} 15 \mathrm{H} 26 \mathrm{O}$ \\
\hline 16 & 30.44 & 1753 & 0.33 & 0.58 & lanceol, cis & $\mathrm{C} 15 \mathrm{H} 24 \mathrm{O}$ \\
\hline 17 & 30.98 & 1619 & 0.60 & 0.41 & Iso spathulenol & $\mathrm{C} 15 \mathrm{H} 24 \mathrm{O}$ \\
\hline 18 & 31.46 & 1660 & 1.04 & 0.73 & tau-Cadinol & $\mathrm{C} 15 \mathrm{H} 26 \mathrm{O}$ \\
\hline 19 & 31.90 & 1651 & 8.12 & 8.98 & $\alpha$-Bisabolol oxide B & $\mathrm{C} 15 \mathrm{H} 26 \mathrm{O} 2$ \\
\hline 20 & 32.14 & 1654 & 0.56 & nd & Bisabolol oxide A & $\mathrm{C} 15 \mathrm{H} 26 \mathrm{O} 2$ \\
\hline 21 & 32.22 & 1681 & nd & 2.57 & Santalol, cis, $\alpha-$ & $\mathrm{C} 15 \mathrm{H} 24 \mathrm{O}$ \\
\hline 22 & 32.98 & 1657 & 7.41 & 6.86 & Bisabolone oxide & $\mathrm{C} 15 \mathrm{H} 24 \mathrm{O} 2$ \\
\hline 23 & 33.12 & 1664 & 1.91 & 1.95 & $\alpha$-Bisabolol & $\mathrm{C} 15 \mathrm{H} 26 \mathrm{O}$ \\
\hline 24 & 34.78 & 1715 & 3.36 & 0.99 & Chamazulene & $\mathrm{C} 14 \mathrm{H} 16$ \\
\hline 25 & 34.87 & 1068 & nd & 0.24 & o-Toluidine & $\mathrm{C} 12 \mathrm{H} 12 \mathrm{~N} 2$ \\
\hline 26 & 35.70 & 1654 & 38.36 & 54.00 & Bisabolol oxide A & $\mathrm{C} 15 \mathrm{H} 26 \mathrm{O} 2$ \\
\hline 27 & 36.22 & 1030 & nd & 0.14 & limonen -6-ol, pivalate & $\mathrm{C} 15 \mathrm{H} 24 \mathrm{O} 2$ \\
\hline 28 & 38.49 & 1833 & 0.29 & 0.14 & 2-Pentadecanone, 6,10,14-trimethyl & $\mathrm{C} 18 \mathrm{H} 36 \mathrm{O}$ \\
\hline 29 & 40.40 & 1830 & 4.73 & 5.32 & En-in-dicycloether & $\mathrm{C} 13 \mathrm{H} 12 \mathrm{O} 2$ \\
\hline 30 & 41.07 & 1830 & 0.49 & 2.30 & $\begin{array}{l}\text { 1,6-Dioxaspiro[4.4]non-3-ene, } \\
\text { 2-(2,4-hexadiynylidene) }\end{array}$ & $\mathrm{C} 13 \mathrm{H} 12 \mathrm{O} 2$ \\
\hline 31 & 41.80 & 1650 & nd & 0.14 & 4-Methyl-2H-pyrano[6,5-h]-2H-chromen-2-one & C13H10O3 \\
\hline 32 & 42.60 & 1934 & nd & 0.26 & Azulen-2-ol,1,4-dimethyl-7-(1-methylethyl) & $\mathrm{C} 15 \mathrm{H} 18 \mathrm{O}$ \\
\hline 33 & 46.66 & 1542 & nd & 0.23 & Geranyl isovalerate & $\mathrm{C} 15 \mathrm{H} 26 \mathrm{O} 2$ \\
\hline 34 & 46.83 & 2200 & nd & 0.15 & Docosane & C27H56 \\
\hline 35 & 47.84 & 2066 & 0.19 & 0.53 & 9,12-Octadecadienoic acid $(\mathrm{Z}, \mathrm{Z})$ & $\mathrm{C} 18 \mathrm{H} 32 \mathrm{O} 2$ \\
\hline 36 & 52.51 & 2600 & 0.31 & 0.26 & Hexacosane & C26H54 \\
\hline 37 & 54.61 & 2375 & 1.04 & 0.81 & 9-Octadecenamide & $\mathrm{C} 18 \mathrm{H} 35 \mathrm{NO}$ \\
\hline 38 & 57.91 & 2600 & 0.90 & 1.14 & Hexacosane & C26H54 \\
\hline
\end{tabular}

nd = not determined 
YIELD OF CHAMOMILE ESSENTIAL OIL EXTRACTION

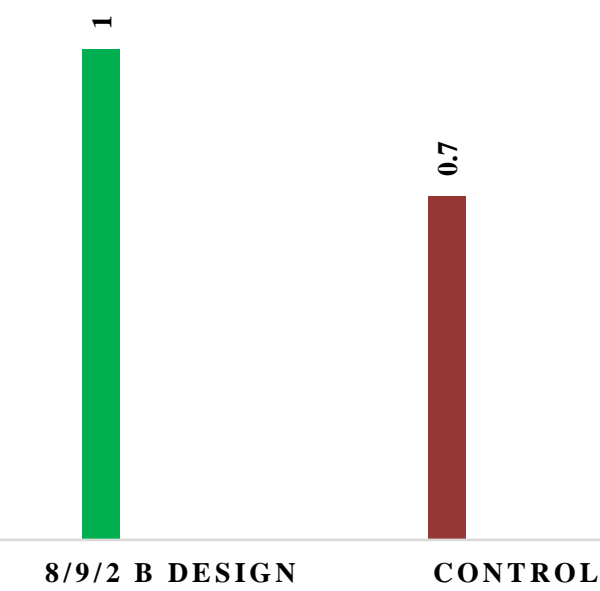

Fig 5. Yield of chamomile essential oil extraction

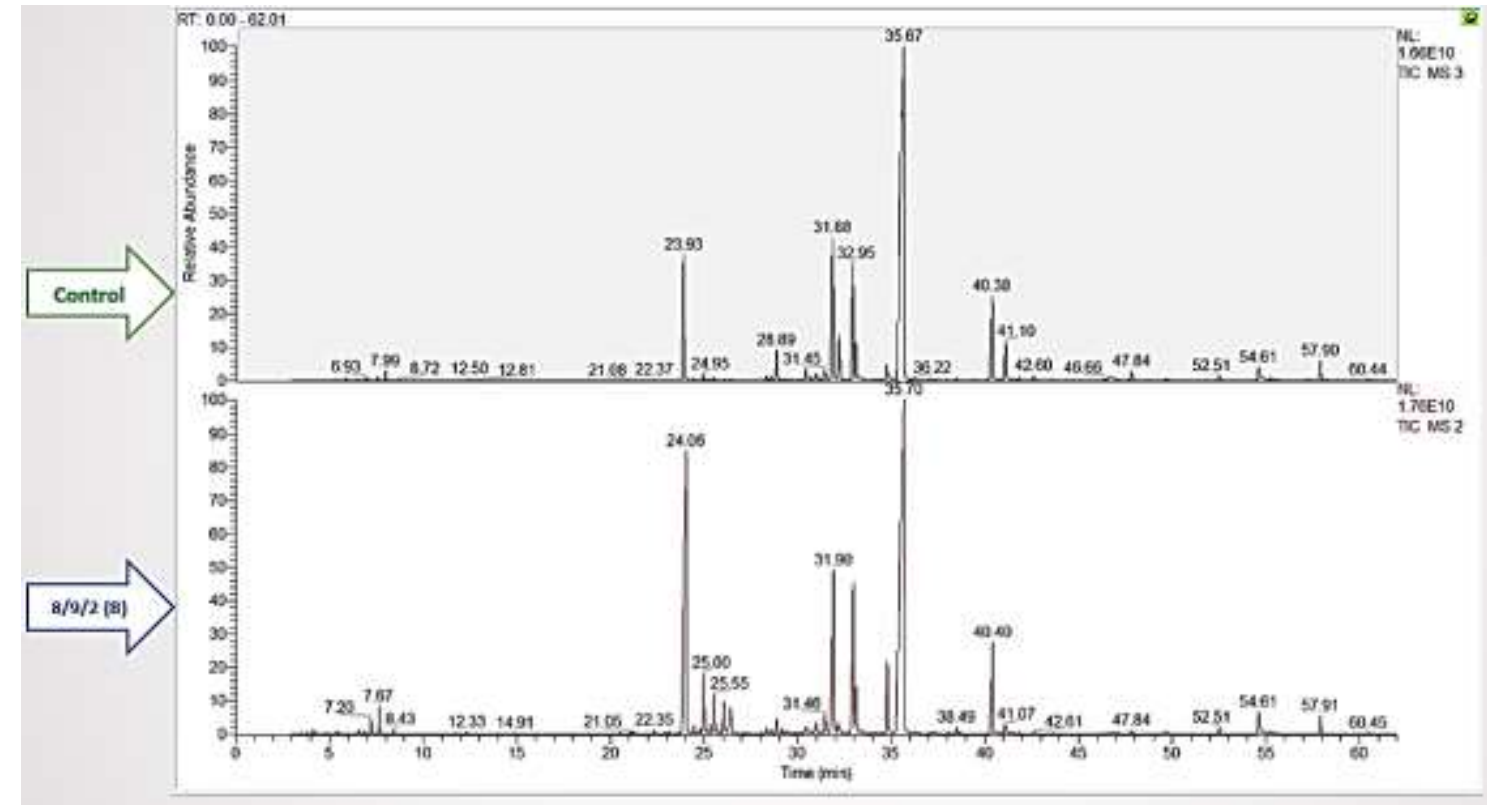

Fig 6. GC-MS chromatogram of chamomile EO 8/9/2 (B) design and control 


\section{Effect of New Solar-Drying Designs for Chamomile Essential Oil Yield and Its Chemical Constituents in Egypt}

of chamomile 8/9/2 (B) design of solar-assisted stack dryer and control. After the significant range results of chamomile chemical constituents of essential oil between 8/9/2 (B) design of solar-assisted stack dryer and control, in order to enhance and ensure that the significant range of chamomile chemical constituents of essential oil, probably, the difference in the essential oil component ratio may affect the biological activity of each. Chamomile volatile oil exhibits potent biological activities, which emphasizes its use in folk medicine. Furthermore, all outcomes regarding the bioactivities components of the main volatile oil components propose that the observed activities of the volatile oils are linked to their chemical composition, where bisabolol and $\alpha$-bisabolol oxide has been found to be the higher active compounds. There was a good connection between antimicrobial, total phenolic content, and antioxidant capacity of the extracts (Kazemi 2015).

\section{Conclusion}

The effect of new solar-drying designs for chamomile volatile oil yield and its chemical constituents in Egypt have been applied for medicinal and aromatic plant especially chamomile plant in Egypt. The drawbacks of the traditional drying method were overcome. In addition to preserving the chemical components and percentage of essential oil plants. The technology of solar-drying provides an alternative that can dry the medicinal and aromatic plants in clean. It saves time, energy, occupies less area, improves the quality of products, saves the environment, and makes the manufacture more efficiently.

\section{Acknowledgment}

All the authors provide their respects to the Deanship of the Faculty of Agriculture at Ain Shams University Department of Food Science for encouraging this work through the research work group, and Chemistry of Natural and
Microbial Products Department, Pharmaceutical Industry Division, National Research Centre, Egypt.

\section{References}

Adapa, PK; Sokhansanj, S; Schoenau, GJ (2002) Performance study of a re-circulating cabinet dryer using a household dehumidifier. Drying Technology 20, 1673-1689.

Ajay, C; Orsunil, KS; Deepak, DP (2009) Design of solar dryer with turbo ventilator and fireplace. In International Solar Food Processing Conference, pp 1-5.

Alves-Filho, O (2002) Combined innovative heat pump drying technologies and new cold extrusion techniques for production of instant foods. Drying Technology 20, 1541-1557.

Brunke, EJ; Hammerschmidt, EJ; Schmaus, G (1992) Headspace analysis of selected European medicinal plants. In Proceedings of the $12^{\text {th }}$ International Congress of Flavours, Fragrances and Essential Oils, pp 105-124.

Giri, SK; Prasad, S (2007) Drying kinetics and rehydration characteristics of microwave-vacuum and convective hot-air dried mushrooms. Journal of Food Engineering, 78, 512-521.

Grgesina, D.; Mandić, ML; Karuza, L; Klapec, T; Bočkinac, D (1995) Chemical composition of different parts of Matricariachamomilla. Prehrambeno-tehnološkaibiotehnološkarevija, 33, 111-113.

Hedrick, UP (1972). Sturtevant's Edible Plants of the World, New York. USA.

Hernandez, JA; Pavon, G; Garcia, MA (2000) Analytical solution of mass transfer equation considering shrinkage for modeling food-drying kinetics. Journal of Food Engineering, 45, $1-10$.

Kazemi, M (2015) Chemical composition and antimicrobial activity of essential oil of Matricariarecutita. International Journal of Food Properties, 18, 1784-1792. 
Klaus, AS; Beatović, DV; Nikšić, MP; Jelačić, SĆ; Nedović, VK; Petrović, TS (2008) Influence of ethereal oils extracted from Lamiaceae family plants on some pathogen microorganisms. Zbornik Maticesrpskezaprirodnenauke, $115,65-74$.

Lange, DAGMAR (2006) International Trade in Medicinal and Aromatic Plants, Frontis $p p$ 155-170.

Pierce, RO; Thompson, TL (1980) Management of solar and low temperature grain drying systems. Part II: Layer drying and solution to the over-drying problem. Transaction of the ASAE, 231020-1023.

Ramaswamy, HS; Marcotte, M (2005) Food processing: principles and applications. CRC Press.
Senadeera, W; Bhandari, BR; Young, G; Wijesinghe, B (2003) Influence of shapes of selected vegetable materials on drying kinetics during fluidized bed drying. Journal of Food Engineering 58, 277-283.

Sosle, V; Raghavan, GSV; Kittler, R (2003) Low-temperature drying using a versatile heat pump dehumidifier. Drying Technology 21, 539-554.

Stefanini, MB; Figueiredo, RO; Ming, LC; Júnior, AF (2001) Antimicrobial activity of the essential oils of some spice herbs. In International Conference on Medicinal and Aromatic Plants 597, 215-216. 
مجلة اتحاد الجامعات العربية للعلوم الزراعية، جامعة عين شمس، القاهرة، مصر

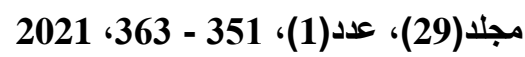

Website: http://ajs.journals.ekb.eg

عزل وتعريف بكتريا غير بادئ حمض اللاكتيك من الجبن البراميلي التقليدي

[23]

$$
\text { احمد مصطفي على" - يوسف مرسي الكناني - ايهاب السيد عمارة - عثمان عبدالعليم عيطه }
$$

قسم علوم الاغذية- كلية الزراعة - جامعة عين شمس - ص. ب 68 - 11241 حدائق شبرا - القاهرة - مصر عبدر

*Corresponding author: ahmed_mostafa@agr.asu.edu.eg

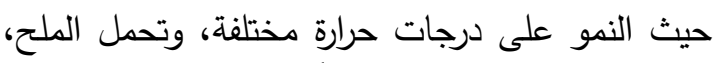

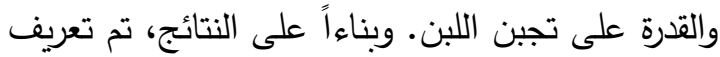

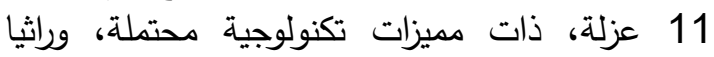

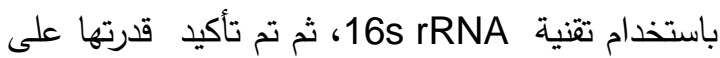
النمو وتكوين الحموضة في اللبن الفرز خلال 48 ساعة. Ent. durans(1), وتم تعريف الـ 11 عزلة على فلى أنهاع النها Ent. faecalis (5), Lb. paraplantarum (1), Lb. plantarum (3), and Lb. rhamnosus (1), والتي ثبت نشاطها جميعًا في اللبن الفرز وأظهرت نشاطا

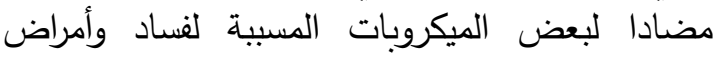

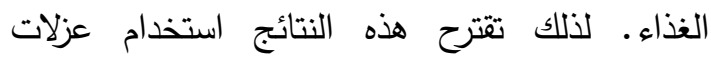

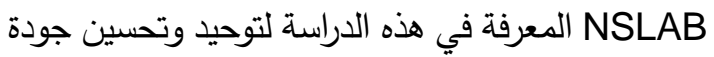
وسلامة الجبن البراميلي والاصناف الفي لفرعية الأخرى ذات

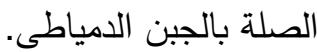

تلعب بكتيريا غير بادئ حض اللاكتيك دورًا هاما في جودة وسلامة الجبن البراميلي (NSLAB) التقليدي وهو من اصناف الجبن الدمياطى. لذاطلك كان التهان

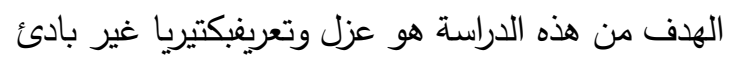
حض اللاكتيكذات المميزات التكنولوجية الدحتملة من فئن الجبن البراميلي التقليدي حيث تم تجميع عدد 33عينة التئن من الجبن البراميلى عشوائياً من متاجر التجزئة بمنطقة تهنة

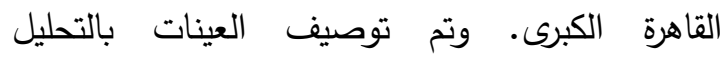
القيزيوكيميائي، والبنائى والميكروبيولوجي. وتوبئ وتم عزل عدد

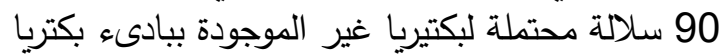

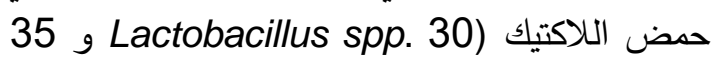
MRS وذلك على بيئات (Enterococcus spp. و KF Streptococci المتخصصة وتم تقييمها من 